\title{
Vergaderdata NVMO-PMO 2007-2008
}

De NVMO-werkgroep Praktisch Medisch Onderwijs (PMO) heeft als doelstelling: het uitwisselen van informatie over praktisch medisch onderwijs, discussies over ontwikkelingen en plannen aan de medische faculteiten, en het formuleren van adviezen ten aanzien van praktisch medisch onderwijs.

De NVMO-PMO werkgroep belegt vijf bijeenkomsten in het jaar, waarvan vier in het Universitair Medisch Centrum Utrecht (UMCU) en één tijdens het NVMOcongres. De bijeenkomsten in het UMCU vinden plaats van 14.00-16.30 uur in Vergaderzaal 2.

De data voor de periode 2007-2008 zijn als volgt:

1. Woensdag 26 september 2007
2. Donderdag 15 november 2007 (tijdens NVMO)

3. Dinsdag 15 januari 2008

4. Woensdag 19 maart 2008

5. Donderdag 15 mei 2008

NVMO-leden worden van harte uitgenodigd voor het bijwonen van de bijeenkomsten. Heeft u vragen over de bijeenkomsten, of een onderwerp dat u graag tijdens een NVMO-PMO werkgroep wilt inbrengen? Schroomt $\mathrm{u}$ dan niet om contact op te nemen met de coördinatoren van de werkgroep: Monica van de Ridder (j.m.m.vanderidder@umcu.nl) en Maarten Verwijnen (M.Verwijnen@sk.unimaas.nl). 